\title{
INVESTASI DALAM PERSEPEKTIF ISLAM
}

\author{
Indah Yuliana \\ Jurusan Manajemen Fakultas Ekonomi Universitas Islam Negeri (UIN) Malang \\ Jl. Gajayana No. 50, Telepon (0341) 558881,Fax.(0341) 558881, \\ E-mail: feuinmlg@yahoo.co.id
}

\begin{abstract}
Investment is a part of important thing in investment economic that is activity including risk because it faces with uncertainty element. Islam as comprehensive religion in its studying and norm manage the whole human activity in all field. Islam motivates every person for working and reaching wealth as much as possible. It allows every human to look for a wealth as much as he or she can, increase, use during it does not disturb norm of religion. Islamic economic investment is different from economic investment non Moslem. It is primarily caused in Islamic economic investment without using interest level in calculating investment. Asset or money is assessed by Allah as a fundamental tool in this life. Therefore, asset and financial capital are not allowed to gain for their selves but it should be by human effort. That is one of causes why using money in excessive interest forbidden by Al-Qur'an. Investment in Islam is muamalah activity that is very suggested because it makes asset to be productive and gives advantage for others. Investment in perspective of economic Islam is not only about profit which is gained from investment activity, but there are several motivations of investment in Islam.
\end{abstract}

Key word: Investasi,spekulasi, pertumbuhan ekonomi

Setiap manusia memerlukan harta untuk mencukupi segala kebutuhan hidupnya. Karenanya, manusia akan selalu berusaha memperoleh harta kekayaan tersebut. Salah satunya melalui kegiatan investasi. Kata investasi merupakan kata adopsi dari bahasa inggris, yaitu investmen. Kata invest sebagai kata dasar dari investmen memiliki arti menanam. Dalam Webster's New Collegiate Dictionary, kata invest didefinisikan sebagai to make use of for future benefits or advantages and commit (money) in order to earn a financial return. Kemudian kata investment diartikan sebagai the outly of money use for income or profit. Sedangkan dalam bahasa arab, Ististmar, berarti investasi, berasal dari kata ististmar yang artinya menjadikan berbuah (berkembang) dan bertambah jumlahnya. Ististmar artinya menjadikan harta berubah (berkembang) dan bertambah jumlahnya. Investasi adalah merupakan bagian penting dalam perekonomian. Investasi adalah kegiatan usaha yang mengandung risiko karena 
berhadapan dengan unsur ketidakpastian. Dengan demikian, perolehan kembaliannya (return) tidak pasti dan tidak tetap. Investasi merupakan penempatan sejumlah dana pada saat ini dengan harapan untuk memperoleh keuntungan di masa yang akan datang (Halim, 2005:4).

Menurut Tandelilin (2001:5) alasan orang melakukan investasi adalah : (1) Untuk mendapatkan kehidupan yang layak di masa depan. Seseorang yang bijaksana akan berfikir bagaimana meningkatkan taraf hidupnya dari waktu ke waktu atau setidaknya berusaha bagaimana mempertahankan tingkat pedapatannya yang sekarang agar tidak berkurang di masa datang. (2) Mengurangi resiko inflasi. Dengan melakukan investasi dalam kepemilikan perusahaan atau obyek lain, seseorang dapat menghindarkan diri dari resiko penurunan nilai kekayaan atau hak milik akibat adanya pengaruh inflasi. (3) Dorongan untuk menghemat pajak. Beberapa negara di dunia banyak melakukan kebijakan yang bersifat mendorong tumbuhnya investasi di masyarakat melalui pemberian fasilitas perpajakan kepada masyarakat yang melakukan investasi pada bidang usaha tertentu. Tujuan investasi adalah untuk meningkatkan kesejahteraan di masa sekarang ataupun masa depan. Menurut Jumingan (2009:5) manfaat dari dilaksanakannya investasi adalah sebagai berikut : (1) Menambah pendapatan nasional, (2) Meningkatkan stabilitas penerimaan, melalui diversifikasi ekspor, meproduksi barang-barang substitusi, (3) Menambah lapangan kerja, (4) Memanfaatkan bahan baku lokal. Adapun dasar keputusan investasi menurut Tandelilin (2001:6) terdiri dari : (a) Return. Alasan utam orang berinvestasi adalah mempeoleh keuntungan. Dalam manajemen investasi tingkat keuntungan investasi disebut return. Suatu hal yang sangat wajar jika investor menuntut tingkat return tertentu atas dana yang dilakukannya merupakan kompensasi biaya kesempatan (opportunity cost) dan resiko penurunan daya beli akibat adanya pengaruh inflasi. Dalam berinvestasi perlu dibedakan antara return yang diharapkan (expected return) dan return yang terjadi (realized return). Return yang diharapkan merupakan tingkat retur yang diantisipasi investor di masa datang. Sedangkan return yang terjadi atau return aktual merupakan return yang telah diperoleh investor di masa lalu. Antara tingkat return yang diharapkan dan tingkat return aktual yang diperoleh investor dari investasi yang dilakukan mungkin saja berbeda. Perbedaan antara return yang diharapkan resiko yang harus selalu dipertimbangkan dalam proses investasi. 
Sehingga dalam berinvestasi, disamping memperhatikan tingkat return, investasi harus selalu mempertimbangkan tingkat resiko suatu investasi. (b) Risk. Korelasi langsung antara pengembalian dengan resiko, yaitu: semakin tinggi semakin tinggi pengembalian. Oleh karena itu investor harus menjaga tingkat resiko dengan pengembalian yang seimbang (c) The time factor. Jangka waktu adalah hal penting dari definisi investasi. Investor dapat menanamkan modalnya pada jangka pendek, jangka menengah, atau jangka panjang. Pemilihan jangka waktu investasi sebenarnya merupakan suatu hal penting yang menunjukkan ekspektasi atau harapan dari investor. Investor selalu menyeleksi jangka waktu dan pengembalian yang bisa memenuhi ekspektasi dari pertimbangan pengembalian dan resiko

\section{Investasi dalam Islam}

Islam mendorong setiap manusia untuk bekerja dan meraih sebanyakbanyaknya materi. Islam membolehkan setiap manusia mengusahakan harta sebanyak ia mampu, mengembangkan, memanfaatkannya sepanjang tidak melanggar ketentuan agama. Sektor swasta didorong untuk berkembang semaksimal mungkin. Motif untuk menghasilkan produk bermutu tinggi dengan harga yang murah agar unggul dalamn persaingan bebas, akan mendorong dan menumbuhkan kreativitas manusia secara optimal. Atas dasar ini, pengembangan sumber daya manusia yang unggul, beriman, berpengetahuan, berketrampilan tinggi dengan kepribadian teguh, mutlak diperlukan.

Investasi adalah merupakan bagian penting dalam perekonomian. Investasi adalah kegiatan usaha yang mengandung risiko karena berhadapan dengan unsur ketidakpastian. Dengan demikian, perolehan kembaliannya (return) tidak pasti dan tidak tetap. Investasi berbeda dengan membungakan uang, karena membungakan uang adalah kegiatan usaha yang kurang mengandung risiko karena perolehan kembaliannya berupa bunga yang relatif pasti dan tetap(Antonio, 2001:150). Investasi dalam ekonomi Islam amat berbeda dengan investasi ekonomi non muslim, perbedaan ini terjadi terutama karena pengusaha Islam tidak menggunakan tingkat bunga dalam menghitung investasi. Dimana harta atau uang dinilai oleh Allah sebagai Qiyaman (Shihab,1996:403) yaitu sarana pokok kehidupan sesuai dengan Firman Allah dalam alNisa': 5 
Dan janganlah kamu serahkan kepada orang-orang yang belum Sempurna akalnya, harta (mereka yang ada dalam kekuasaanmu) yang dijadikan Allah sebagai pokok kehidupan. Berilah mereka belanja dan pakaian (dari hasil harta itu) dan ucapkanlah kepada mereka kata-kata yang baik.

Karena itu pula harta atau modal tidak boleh menghasilkan dari dirinya sendiri, tetapi harus dengan usaha manusia. Ini salah satu sebab mengapa membungakan uang dalam bentuk riba dilarang oleh al-Qur'an. Salah satu hikmah pelarangan riba, serta pengenaan zakat adalah untuk mendorong aktivitas ekonomi, perputaran dana serta sekaligus mengurangi spekulasi serta penimbunan. Dalam konteks ini Al-Qur'an mengingatkan (Shihab,1996:406)

Hai orang-orang yang beriman, Sesungguhnya sebahagian besar dari orang-orang alim Yahudi dan rahib-rahib Nasrani benar-benar memakan harta orang dengan jalan batil dan mereka menghalang-halangi (manusia) dari jalan Allah. dan orang-orang yang menyimpan emas dan perak dan tidak menafkahkannya pada jalan Allah, Maka beritahukanlah kepada mereka, (bahwa mereka akan mendapat) siksa yang pedih,(Qs At-taubah : 34)

Seorang muslim boleh memilih tiga alternatif atas dananya yaitu: (1) memegang kekayaannya dalam bentuk uang kas (idle cash), (2) memegang tabungannya dalam bentuk asset tanpa berproduksi seperti deposito bank, pinjaman, real estate, permata atau (3) menginvestasikan tabungannya (seperti memiliki proyekproyek yang menambah persediaan kapital nasional). (Mertwally,1995:70)

Dalam Al-Qur'an terdapat ayat-ayat yang secara tidak langsung telah memerintahkan kaum muslimin untuk mempersiapkan hari esok secara lebih baik. Ada beberapa ayat dalam Al-Qur'an yang dapat dijadikan sandaran dalam berinvestasi antara lain, dalam Surat Al-Baqarah(2) : 261, Allah berfirman yang artinya:

"Perumpamaan (nafkah yang dikeluarkan oleh) orang-orang yang menafkahkan hartanya di jalan Allah adalah serupa dengan sebutir benih yang menumbuhkan tujuh bulir, pada tiap-tiap bulir seratus biji. Allah melipat gandakan (ganjaran) bagi siapa yang dia kehendaki. dan Allah Maha luas (karunia-Nya) lagi Maha Mengetahui".

Ayat diatas dapat merupakan contoh kongkrit dari kita berinvestasi yang dimuai dengan (sebutir benih) menjadi tujuh bulir dan akhirnya menjadi tujuh ratus 
biji. Nampaknya Al-qur'an telah memberikan panduan investasi (walaupun dalam hal ini adalah infaq, yang berdimensi ukhrawi), namun bila banyak orang yang melakukan infaq maka akan menolong ratusan bahkan ribuan orang yang miskin untuk dapat berproduktifitas ke arah yang lebih baik. Nampaknya multiplier effect dari infaq bukan hanya berpengaruh pada akhirat saja namun juga mempengaruhi dimensi dunyawiyah.

\section{Surat An-Nisa : 9}

"Dan hendaklah takut kepada Allah orang-orang yang seandainya meninggalkan dibelakang mereka anak-anak yang lemah, yang mereka khawatir terhadap (kesejahteraan) mereka. oleh sebab itu hendaklah mereka bertakwa kepada Allah dan hendaklah mereka mengucapkan perkataan yang benar".

Ayat diatas memerintahkan kepada kita agar tidak meninggalkan keturunan yang lemah baik moril maupun materil. Seolah ingin memberikan anjuran agar selalu memperhatikan kesejahteraan (dalam hal ini secara ekonomi) yang baik dan tidak meninggalkan kesusahan secara ekonomi, nampaknya Al-Qur'an telah jauh hari mengajak umatnya untuk selalu memperhatikan kesejahteraan yang salah satu caranya adalah dengan berinvestasi. Dalam Surat Al-hasyr (59) : 18 telah disebutkan artinya sebagai berikut:

"Hai orang-orang yang beriman, bertakwalah kepada Allah dan hendaklah setiap diri memperhatikan apa yang Telah diperbuatnya untuk hari esok (akhirat); dan bertakwalah kepada Allah, Sesungguhnya Allah Maha mengetahui apa yang kamu kerjakan".

Dalam ayat diatas dapat ditafsirakan bahwa manusia bukan saja memperhatikan kehidupan akhirat namun harus pula memperhatikan kehidupan dunia karena kata ghad bisa berarti besok pagi, lusa atau waktu yang akan datang. Investasi akhirat dan dunia nampaknya menjadi suatu hal yang wajib bagi orang yang beriman kepada Allah dengan selalu Taqwa kepada-Nya.

Dalam Islam investasi merupakan kegiatan muamalah yang sangat dianjurkan, karena dengan berinvestasi harta yang dimiliki menjadi produktif dan juga mendatangkan manfaat bagi orang lain. Al-Quran dengan tegas melarang aktivitas penimbunan terhadap harta yang dimilki. Dalam sebuah hadits, Nabi Muhammad Saw bersabda:"Ketahuilah, Siapa yng memelihara anak yatim, sedangkan anak yatim tersebut itu memilki harta maka hendaklah ia menginvestasikannya 
(membinisniskannya) janganlah ia membiarkan harta itu idle, sehingga harta itu terus berkurang lantaran zakat. Dalam perspektif ekonomi Islam, investas bukanlah melulu bercerita tentang berapa keuntungan materi yang bisa didapatkan melalaui investasi tersebut. Akibat implementasi mekanisme zakat, maka asset produktif yang dimilki seseorang pada jumlah tertentu (memenuhi batas nisab zakat) akan selalu dikenakan zakat, sehingga hal ini akan mendorong pemiliknya untuk mengelolanya melalui investasi. Dengan demikian melalui investasi tersebut pemilik asset memilki potensi mempertahankan jumlah dan nilai assetnya. Aktivitas investasi dilakukan lebih didasarkan pada motifasi social yaitu membantu sebagian masyarakat yang tidak memilki modal namun memilki kemampuan berupa keahlian (skill) dalam menjalankan usaha, baik dilakukan dengan musyarakah maupun dengan berbagi hasil (mudharabah). Investasi dalam Islam bukan hanya dipengaruhi faktor keuntungan materi, tapi juga sangat dipengaruhi oleh faktor syariah (kepatuhan pada ketentuan syariah) dan faktor sosial (kemaslahatan umat). Harta yang dimilki seorang muslim tidak boleh dimanfaatkan dan dikembangkan dengan cara yang bertentangan dengan syariat Islam. Islam telah melarang aktivitas perjudian, riba, penipuan, serta investasi di sektor-sektor maksiat. Sebab aktiviats aktivitas semacam ini justru akan menghambat produktivitas manusia.

Menurut Quraish Shihab (1996: 403), dalam Islam harta atau uang dinilai oleh Allah sebagai Qiyaman yaitu sarana pokok kehidupan sesuai dengan Firman Allah

Dan janganlah kamu serahkan kepada orang-orang yang belum Sempurna akalnya, harta (mereka yang ada dalam kekuasaanmu) yang dijadikan Allah sebagai pokok kehidupan. berilah mereka belanja dan Pakaian (dari hasil harta itu) dan ucapkanlah kepada mereka kata-kata yang baik.

Karena itu pula harta atau modal tidak boleh menghasilkan dari dirinya sendiri, tetapi harus dengan usaha manusia. Ini salah satu sebab mengapa membungakan uang dalam bentuk riba dilarang oleh al-Qur'an. Salah satu hikmah pelarangan riba, serta pengenaan zakat adalah untuk mendorong aktivitas ekonomi, perputaran dana serta sekaligus mengurangi spekulasi serta penimbunan. 


\section{Prinsip-prinsip ekonomi Islam dalam berinvestasi}

Prinsip-prinsip Islam dalam muamalah yang harus diperhatikan oleh pelaku investasi syariah (pihak terkait) adalah: (Huda dan Mustofa, 2008:24)

1. Tidak mencari rizki pada hal yang haram, baik dari segi zatnya maupun cara mendapatkannya, serta tidak menggunakannya untuk hal-hal yang haram.

2. Tidak mendzalimi dan tidak didzalimi.

3. Keadilan pendistribusian kemakmuran.

4. Transaksi dilakukan atas dasar ridha sama ridha.

5. Tidak ada unsur riba, maysir (perjudian/spekulasi), dan gharar ketidakjelasan/samar-samar).

\section{Objectives (sasaran) sistem ekonomi Islam.}

Perbaikan hidup, baik secara materi maupun spiritual, adalah merupakan akar dari semua objective (sasaran) ekonomi Islam. Sendi-sendi ajaran Islam semuanya tertuju dan mendukung agar manusia menjadi khalifatullah di muka bumi yang fana ini. Syariah telah mengatur hubungan manusia dengan saudaranya sesama manusia, antara pimpinan dan yang dipimpin, antara atasan dan bawahan, antara kaya dan miskin secara syariah. Juga telah mengatur hubungan manusia dengan hartanya dan dengan anak-anaknya secara syariah karena akan memberikan mashlahat bagi manusia dan menolak segala kemudlaratan. Maka untuk mencapai kemashlahatan itu perlu ada beberapa objective (sasaran) di dalam sistem ekonomi Islam, di antaranya :

1. Meningkatkan pertumbuhan ekonomi (economic growth). Pertumbuhan ekonomi merupakan tujuan dari semua sistem ekonomi termasuk sistem ekonomi Islam. Meningkatnya GNP, NNP atau NI merupakan salah satu indikator keberhasilan ekonomi suatu bangsa. Oleh karena itu semua sistem harus dapat meningkatkan hal ini. Ekonomi Islam itu tetap ekonom al-Islam. Adalah hal yang mendasar, yang dapat membedakan antara sistem Islam dengan sistem yang lainnya. Berbeda dengan sistem lain, sistem ekonomi Islam dalam hal ini harus memperhatikan dua hal yaitu halal dan haram. Ekonomi konvensional memasukkan segala jenis barang dan jasa dalam komponen GNP-nya, tetapi dalam Islam harus selektif, mana jenis barang dan jasa yang dapat dimasukkan. 
2. Menciptakan harga yang stabil. Stabilitas harga ini merupakan perkara yang sangat penting, bukan hanya dirasakan oleh ekonom atau politikus tetapi juga sangat dirasakan oleh rakyat kebanyakan. Karena itu ekonomi Islam harus menciptakan ini dengan jalan memfungsikan kekayaan yang tidak produktif (idle money) dan menghapuskan segala jenis spekulasi.

3. Meningkatkan economic efficiency. Dalam masalah efficiency ini ada beberapa poin yang kita harus berbeda dengan ekonomi conventional. i) Dalam ekonomi konvensional, individual benefit sama dengan social benefit. Tetapi Islam melihatnya tidak demikian. Social benefit kadang-kadang tidak sama dengan individual benefit. Bahwa social benefit itu bukanlah sekedar merupakan gabungan dari tiap-tiap individual benefit. ii) Konsumen akan membeli sesuatu manakala dia mendapatkan manfaat yang sama dengan harga yang ia bayarkan. Padahal daya beli berbeda-beda. Berarti bahwa harga pasar yang dikatakan sebagai fair price hanya ditentukan oleh orang yang memiliki kemampuan beli tinggi. Tentunya yang income-nya kecil akan dirugikan

4. Pemerataan alokasi income. Dalam hal ini Islam sudah jelas tidak menginginkan pengalokasian dan penguasaan kekayaan oleh sebagian orang. Allah swt. berfirman di dalam surah Al Hasyr (59): 7 berikut:

\begin{abstract}
“Apa-apa (harta rampasan) diberikan Allah kepada Rasul-Nya dari penduduk negeri (orang-orang kafir), maka adalah untuk Allah, untuk Rasul, untuk karib kerabat (Rasul), anak-anak yatim, orang-orang miskin dan musafir, supaya jangan sampai harta itu beredar di antara orang-orang kaya saja di antara kamu. Apa-apa yang diberikan Rasul kepadamul maka terimalah dia, dan takutlah kepada Allah. Sesungguh-Nya Allah amat keras siksaan-Nya."Syariah Islam memerintahkan agar kita memberikan balasan (upah) secara adil. Setiap orang dibayar sesuai dengan pekerjaannya.
\end{abstract}

Serta berdasarkan surah An-Najm (53) ayat 39 yang artinya adalah:

"Dan tidaklah untuk manusia melainkan apa-apa yang diusahakannya."

\title{
Pedoman berinvestasi dalam Islam
}

Seorang pengusaha muslim sama sekali berbeda dengan yang lainnya. Dia memiliki tanggung jawab ganda, yaitu tanggung jawab akhirat dan tanggung jawab duniawi. 
Pengusaha Muslim harus lebih berhati-hati berinteraksi dengan harta. Karena harta itu adalah hiasan dunia yang mengandung fitnah.

a) Pengusaha muslim bukan hanya sekedar sebagai economic man tetapi juga sebagai Islamic economic man. Kalau pengusaha traditional (non muslim) selalu berusaha untuk mendapatkan keuntungan yang lebih besar. Di mana keuntungan ini hanya diukur dari selisih pendapatan dan biaya saja. Tetapi sebagai seorang pengusaha muslim, dia berkewajiban untuk menjadi manusia yang multazim dengan dianya, dia juga sebagai mursyid. Tugasnya menciptakan al falah sebesar-besarnya. Karena seperti telah kita ketahui bahwa al falah merupakan gabungan dari keberhasilan dunia dan keberhasilan akhirat. Ikatan ekonomi dengan ad-dien harus dapat menciptakan perubahan yang nyata pada sudut pandang seorang pengusaha muslim. Dia harus bisa menentukan mana yang terpenting dari penting-penting dan menentukan target yang harus dicapai dalam jangka pendek dan jangka panjang.

b) Pengusaha muslim harus mencari komoditi yang halal dan menjauhkan komoditi yang haram. Hal ini harus dilakukan meskipun permintaan sangat banyak. Pengusaha muslim tidak boleh menginvestasikan hartanya dalam proyek-proyek yang akan menghasilkan atau yang berhubungan dengan daging babi, khamar, perjudian, riba dan lain-lain. Sampai juga kepada komoditi yang dapat dikategorikan sebagai pemborosan dan komoditi yang dianggap sebagai barang subhat.

c) Seorang muslim tidak hanya mengurusi dirinya dan mencari kemashlahatannya sendiri. Tetapi dia bertanggung jawab terhadap masyarakatnya secara umum. Berarti mashlahat baru dikatakan mashlahat kalau itu dapat memberikan maslahat kepada masyarakat karena maslahat umum adalah maslahatnya. Memperhatikan kepentingan orang bukan hanya berupa bantuan langsung saja, tetapi juga secara tidak langsung. Seperti membuat proyek atau investasi yang nantinya akan dapat mengangkat derajat fakir miskin secara ekonomi.

d) Seorang pengusaha muslim dapat merealisasikan objective sistem ekonomi Islam. Objective ini bukan omong kosong atau hanya masalah teori yang hanya disampaikan di dalam ruangan tetapi itu harus dilaksanakan dalam kehidupan 
nyata. Untuk merealisasikan ini bukan hanya tugas siasah maliyah (seperti pajak) dan zakat saja. Tetapi ini juga merupakan tanggung jawab para pengusaha tanpa ada pembeda sedikitpun. Objective ekonomi Islam yang memiliki prinsip tidak membahayakan diri sendiri dan orang lain, jangan hanya menjadi kata kiasan saja bila para pengusaha tidak merealisasikannya.

Sedangkan etika seorang produsen dalam lingkaran halal dan haram adalah menjauhi berbagai sifat diatas atau memproduksi sesuatu yang diperbolehkan dalam Islam, diantaranya adalah:

1. Seorang muslim harus menanam apa-apa yang memberikan kemaslahatan dan apa-apa yang didihalalkan.

2. Seorang muslim juga harus memproduksi barang-barang halal, baik halal dikenakan ataupun halal dikoleksi.

3. Diantara produk yang dianjurkan beredar ialah produk yang menguatkan akidah, etika dan moral manusia.

4. Investasi harta dengan cara memberikan keuntungan dan kemaslahan masyarakat pada lembaga atau perusahaan yang sesuai syariah.

5. Memakai sistem bagi hasil dan menjauhi riba

6. Menjauhi aktivitas yang tidak baik dalam produksi seperti jual beli yang tidak jelas, mencuri, merampas, merampas menyuap dan disuap serta berjudi

7. Menjauhi aktivitas menimbun/spekulan karena menimbun bisa merugikan masyarakat banyak disebabkan menahan barang beredar sehingga banyak dari masyarakat yang dirugikan.

8. Jual beli atau perniagaan barang-barang yang halal dan baik

9. Bertransaksi dengan berprisnsip syari'ah seperti: titipan, bagi hasil, jual-beli, sewa dan jasa/fee

10. Dalam perdagangan seorang produsen harus bersikap adil.

Dari penjabaran diatas dapat kita ambil kesimpulan bahwa kita harus memperhatikan halal dan haram pada bisnis ataupun usaha kita. Kita harus mendapatkan harta atau penghasilan dengan cara yang baik atau halal dan juga menghindar dari penghasilan yang dicapai dengan cara yang salah atau haram. Begitu juga dalam mempergunakannya harus dengan cara yang halal yang diperbolehkab 
Islam dan tidak mempergunakannya dengan cara yang salah atau dengan cara yang diharamkan Islam. Perbedaan antara halal dan haram bukan saja mengharuskan tujuannya mesti benar, namun sarana untuk mencapai tujuan itu juga haruslah baik. Perintah Al Quran untuk mencari nafkah setelah melakukan ibadah ritual, mengimpliksikan bahwa seseorang hendaknya mengikuti perilaku yang diperkenankan dan dihalalkan dalam mendapatkan penghasilan. Penyucian hati yang dihasilkan oleh ibadah ritual juga hendaknya menyucikan niat dan metode mereka dalam mencari nafkah dengan cara yang halal. Prinsip halal dan haram diimplikasikan secara sama pada saat penggunaan harta itu dan juga pada saat akuisisi. Harta yang halal hendaknya dipergunakan dalam hal yang halal dan dibolehkan. Atau dengan kata lain, penggunaan penggunaan harta itu juga hendaknya dibatasi hanya pada suatu yang halal. Hendaknya kita menyimpan atau menginvestasikan harta pada lembaga atau perusahaan yang halal, seperti bank syariah atau lembaga-lembaga lain yang sesuai syariah. Tidak hanya mementingkan keuntungan semata akan tetapi melihat dari sisi moral yang ada.

Seorang muslim tidak boleh menanam apa-apa yang membahayakan dan apaapa yang diharamkan. Karena itu semua menyebabkan terjadinya kejahatan dan kriminalitas. Seorang muslim juga dilarang memproduksi barang-barang haram, baik haram dikenakan ataupun haram dikoleksi. Jika manusia masih memproduksi barangbarang yang dilarang beredar, maka ia turut berdosa.

Produk yang dilarang keras beredar ialah produk yang merusak akidah, etika dan moral manusia. Dalam Islam juga dilarang Investasi harta dengan cara membahayakan masyarakat, karena merugikan kepentingan umum begitu juga riba, mencuri, merampas dan menimbun semuanya itu merugikan orang lain dan hasil dari harta yang didapatkan adalah batil dan diharamkan oleh Islam. Seorang muslim yang menyuap adalah orang yang dilaknat oleh Allah bagaimanapun caranya. Diharamkan juga memberi upah kepada pekerjaan yang haram. Islam melarang keras perjudian karena perjudian akan merusak generasi bangsa, menyebabkan kemalasan, rusaknya rumah tangga, merusak hubungan persaudaraan dan hanya berangan-anan menjadu kaya dengan mengandalkan keuntungan semata tanpa kerja keras. Sedangkan etika 
produksi dalam lingkaran halal dan haram adalah Seorang muslim harus menanam apa-apa yang memberikan kemaslahatan dan apa-apa yang dihalalkan.

Seorang muslim juga harus memproduksi barang-barang halal, baik halal dikenakan ataupun halal dikoleksi. Diantara produk yang dianjurkan beredar ialah produk yang menguatkan akidah, etika dan moral manusia. Investasi harta dengan cara memberikan keuntungan dan kemaslahan masyarakat pada lembaga atau perusahaan yang sesuai syariah.

Memakai sistem bagi hasil dan menjauhi riba karena riba adalah perbuatan yang merusak tatanan ekonomi dalam segala segi kehidupan serta menjauhi aktivitas yang tidak baik dalam produksi seperti jual beli yang tidak jelas, mencuri, merampas, merampas menyuap dan disuap serta berjudi. Menimbun adalah suatu perbuatan yang sangat merugikan masyarakat banyak karena menimbun menahan barang beredar sehingga banyak dari masyarakat yang dirugikan oleh karena itu hendaknya seorang muslim menjauhi aktivitas menimbun/spekulan. Suatu yang terbaik bagi seorang mukmin adalah jual beli atau perniagaan barang-barang yang halal dan baik serta bertransaksi dengan berprisnsip syari'ah seperti: titipan, bagi hasil, jual-beli, sewa dan jasa/fee demikian juga dalam perdagangan seorang produsen dituntut untuk bersikap adil.

\section{Konsep Halal dan Haram dalam suatu Bisnis}

Semua hal yang menyangkut dan berhubungan dengan harta benda hendaknya dilihat dan dihukumi dengan kriteria halal dan haram. Semua praktekpraktek jahat dan kecurangan yang berhubungan dengan transaksi harta benda dan kekayaan dilarang. Semua larangan itu berdasarkan satu prinsip: jangan ada ketidakadilan dan jangan ada penipuan. Setiap orang bisa melihat aplikasi dari prinsip Al Quran dalam sabda dan perilaku Rasulullah serta para sahabatnya.

Perbedaan antara halal dan haram bukan saja mengharuskan tujuannya mesti benar, namun sarana untuk mencapai tujuan itu juga haruslah baik. Perintah Al Quran untuk mencari nafkah setelah melakukan ibadah ritual, mengimpliksikan bahwa seseorang hendaknya mengikuti perilaku yang diperkenankan dan dihalalkan dalam mendapatkan penghasilan. Penyucian hati yang dihasilkan oleh ibadah ritual juga 
hendaknya menyucikan niat dan metode mereka dalam mencari nafkah dengan cara yang halal.

Rasulullah sangat konsen dengan persoalan yang menyangkut penghasilan dengan cara yang halal. Dia sangat memperhatikan dari mana seseorang memperoleh harta benda. Umar bin Khaththab adalah khalifah yang dengan tegas mempraktekkan formula ini untuk para gubernur dan para pejabat dijajaran pemerintahannya. Disini ditekankan bahwasannya penggunaan harta dengan cara yang baik adalah untuk memperoleh ridha Allah dan juga demi tercapainya distribusi kekayaan yang lebih baik di tengah-tengah masyarakat. Namun demikain Allah tidak akan menerima penggunaan harta (sedekah, zakat dan infak) dimana harta-harta itu dihasilkan dari cara yang tidak halal sebagaimana dalam surah Al Baqarah (2) ayat 267 yang artinya:

"Hai orang-orang yang beriman, nafkahkanlah (di jalan Allah) sebagian dari hasil usahamu yang baik-baik dan sebagian dari apa yang kami keluarkan dari bumi untuk kamu. dan janganlah kamu memilih yang buruk-buruk lalu kamu menafkahkan daripadanya, padahal kamu sendiri tidak mau mengambilnya melainkan dengan memincingkan mata terhadapnya. dan Ketahuilah, bahwa Allah Maha Kaya lagi Maha Terpuji". (Al Baqarah: 267)

Oleh sebab itulah jika sedekah atau infak ingin diterima, maka hendaknya harta tersebut dihasilkan lewat jalan yang halal. Prinsip halal dan haram diimplikasikan secara sama pada saat penggunaan harta itu dan juga pasa saat akuisisi. Harta yang halal hendaknya dipergunakan dalam hal yang halal dan dibolehkan. Atau dengan kata lain, penggunaan penggunaan harta itu juga hendaknya dibatasi hanya pada suatu yang halal. Harta tersebut jangan sampai digunakan untuk perjudian, minuman keras, perzinaan dan apa saja yang dilarang oleh syariah.

Pemilik harta tersebut memiliki kebebasan untuk menyimpan ataupun menginvestasikan harta. Namun dalam dua kasus tersebut, hendaknya mengikuti petunjuk yang telah digariskan oleh Al Quran. Pada saat ia menyimpan harta itu, hendaknya dia mengeluarkan zakat dan kewajiban lain yang berhubungan dengan itu, dan jika ia menginvestasikan harta tersebut, maka hendaknya ia memilih perdagangan yang halal, dan menjauhi perdagangan yang haram, misalnya menanamkan pada investasi yang mengandung riba. Seorang muslim diperintahkan menanamkan modalnya dalam perdagangan yang halal meskipun mungkin akan menghasilkan 
untuk sedikit jika dibandingkan penanaman modal pada wilayah-wilayah yang haram. Tidak hanya mementingkan keuntungan semata akan tetapi melihat dari sisi moral yang ada.

\section{Lingkaran Halal dan Haram Dalam Memproduksi}

Prinsip etika dalam produksi dalam suatu bisnis yang wajib dilaksanakan oleh setiap produsen muslim baik individu maupun komunitas adalah berpegang pada semua yang dihalalkan Allah dan tidak melawati batas. Walaupun daerah halal itu luas, tetapi mayoritas jiwa manusia yang ambisius merasa kurang puas dengan hal itu walaupun banyak jumlahnya. Banyak ditemukan jiwa manusia yang tergiur kepada sesuatu yang haram. Mereka yang mengatakan bahwa "yang haram saja susah apalagi yang halal" perkataan ini adalah perkataan yang hanya ingin mendapatkan sesuatu secara mudah, tidak mau bekerja keras dan hanya ingin memperoleh keuntungan saja tidak mempedulikan norma dan etika agama yang ada

Yusuf Qardhawi berpendapat bahwa seorang muslim tidak boleh menanam apa-apa yang membahayakan dan apa-apa yang diharamkan, seorang muslim juga dilarang memproduksi barang-barang haram baik haram dikenakan ataupun haram dikoleksi dan diantara produk yang dilarang keras beredar ialah produk yang merusak akidah, etika dan moral manusia. Penjelasan dari pokok pembahasan diatas adalah:

1. Seorang muslim tidak boleh menanam apa-apa yang membahayakan dan apa-apa yang diharamkan. Seperti Poppy, Cannabis atau heroin anggur (untuk minuman keras) dan tembakau yang menurut WHO, sains dan hasil riset, berbahaya bagi manusia.

2. Seorang muslim juga dilarang memproduksi barang-barang haram, baik haram dikenakan ataupun haram dikoleksi. Dalam hadis Shahih ditemukan alasan ungkapan diatas:

“Barang siapa dalam Islam melestarikan tradisi buruk, maka baginya dosa dan dosa orang-orang yang melaksanakan, sesudahnya tanpa mengurangi dosa-dosa mereka 
sedikitpun (HR. Ahmad, Muslim, Tirmidzi, Ibnu Majah dari Jasir. Shahih Jami' Shaghir No. 6305)

3. Di antara produk yang dilarang keras beredar ialah produk yang merusak akidah, etika dan moral manusia.

(Ucapan mereka) menyebabkan mereka memikul dosa-dosanya dengan sepenuhpenuhnya pada hari kiamat, dan sebahagian dosa-dosa orang yang mereka sesatkan yang tidak mengetahui sedikitpun (bahwa mereka disesatkan). Ingatlah, amat buruklah dosa yang mereka pikul itu. (An-Nahl: 25)

Allah swt berfirman: dalam Surah An-Nuur (24) ayat 19 yang artinya:

Sesungguhnya orang-orang yang ingin agar (berita) perbuatan yang amat keji itu tersiar di kalangan orang-orang yang beriman, bagi mereka azab yang pedih di dunia dan di akhirat. dan Allah mengetahui, sedang, kamu tidak Mengetahui. (An Nuur: 19).

Menurut Abdullah Abdul Husain At-Tariqi (2004: 181) hal-hal yang diharamkan dalam Islam adalah:

1. Investasi harta dengan cara membahayakan masyarakat.

Islam melarang produksi yang hanya merealisasikan kepentingan pribadi dan membahayakan kepentingan umum. Produksi dan keuntungan dengan cara eksploitasi, tipu daya, eksploitasi kebutuhan dan menimbulkan bahaya bagi kaum miskin dengan cara apapun diharamkan. Hadist yang menunjukkan haramnya produksi barang yang membahayakan adalah sabda NabiSAW:

$$
\text { لا ضرر و لا ضرار }
$$

"Tidak boleh membahayakan diri sendiri dan membahayakan orang lain"

2. Riba

Islam dan agama-agama samawi lainnya mengharamkan riba, karena dalam riba terdapat hal yang membahayakan masyarakat dan ekonomi. Resiko ekonomi menunjukkan bahwa riba merupakan mediasi yang tidak cocok bagi kegiatan ekonomi berdasar beberapa alasan: 
a. Bunga yang dihasilkan oleh pelaku riba tidak dihasilkan dengan cara produksi, tapi diambil dari harta orang lain atau dari sumber masyarakat tanpa didahului oleh proses produksi.

b. Bunga yang dihasilkan akan menyebabkan kemalasan dan nilai tambahnya tanpa usaha dan kerja keras.

c. Riba akan menyebabkan pertambahan nilai inflasi di masyarakat.

d. Riba memberatkan beban peminjam manakala ia tidak mampu melunasi dikarenakan berlipatnya nilai bunga.

3. Jual beli tidak jelas

Gharar merupakan jenis benda yang ditransaksikan tanpa ada kejelasan ukuran dan sifat ketika transaksi berlangsung. Kerelaan sebagai unsur penting dalam jual beli tidak terdapat dalam transaksi ini. Bentuk transaksi ini termasuk transaksi yang mengandung unsur batil.

\section{Pencurian.}

Allah menetapkan hukuman potong tangan karena perbuatan mencuri merupakan bentuk pengkhianatan. Allah berfirman:

"Laki-laki yang mencuri dan perempuan yang mencuri, potonglah tangan keduanya (sebagai) pembalasan bagi apa yang mereka kerjakan dan sebagai siksaan dari Allah. dan Allah Maha Perkasa lagi Maha Bijaksana". (Al Maa-idah: 38).

\section{Perampasan.}

Menguasai harta orang lain secara ilegal. Kaum muslimin telah sepakat bahwa perbuatan ini adalah haram, karena memakan hasil rampasan dikategorikan sebagai memakan harta dengan cara yang batil sesuai dengan firman Allah:

"Hai orang-orang yang beriman, janganlah kamu saling memakan harta sesamamu dengan jalan yang batil, kecuali dengan jalan perniagaan yang berlaku dengan suka sama-suka di antara kamu". (An Nisaa': 29) 
Perampasan diharamkan mengingat adanya unsur mengambil harta orang lain, baik dengan cara paksa dan aniaya, atau juga dengan cara yang tidak menyenangkan jiwa dan meniadakan kerelaan. Perampas harus mengembalikan hartanya. Jika hilang, maka harus menggantikan senilai dengan harta tersebut. Baik sudah mengambil manfaat ataupun belum. Jika rusak, maka harus mengganti barang tersebut.

6. Upah pekerjaan yang haram dilaksanakan, seperti mas kawin zina dan tips bagi dukun.

Mencari harta dengan cara menjual minuman keras, bangkai, babi dan berhala tidak dihalalkan sebagaimana hadis yang diriwayatkan oleh Jabir RA yang menyatakan bahwa Rasulullah saw bersabda:

\section{"Sesungguhnya Allah dan Rasul-nya mengharamkan jual beli minuman keras, bangkai, babi dan berhala."}

\section{Suap.}

Adalah pemberian sesuatu kepada hakim atau orang lain agar memutuskan hukum sesuai yang diinginkan. Hukum suap haram. Pengharaman Islam ini ditujukan untuk menjaga masyarakat dari timbulnya kerusakan dan penganiayaan hukum tanpa hak atau untuk menegakkan keadilan. Kaum muslim telah satu kata tentang larangan suap.

Perkara ini sama dengan mengambil harta dengan cara batil. Nabi bersabda:

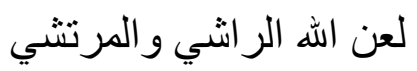

Rasulullah saw. melaknat penyuap dan orang yang disuap.

Suap yang dimaksud mencakup seluruh jenis suap, seperti suap untuk membatalkan hak atau membenarkan yang salah, segala macam tabir kepuasan yang dapat menutupinya, seperti bungkusan dibalik 'hadiah', pinjaman, pemberian, menunaikan kemaslahatan, bantuan, atau adanya menfaat bagi yang 
disuap. Dengan kata lain, semua tindakan apapun yang ditujukan untuk menyuap dengan cara apapun haram hukumnya. Jika dilakukan maka harus dikembalikan kenegara sebagai bentuk hukuman minimal yang ditanggung.

\section{Menimbun/spekulan.}

Menimbun adalah menahan komoditas yang dibutuhakan masyarakat dari sirkulasi pasar dalam satu masa tertentu agar harganya naik. Setelah naik, barang tersebut dijual di pasaran. Penimbunan merupakan bagian perbuatan haram, sesuai dengan sabda Nabi saw:

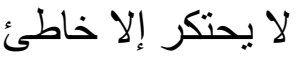

"Hendaklah seseorang tidak menimbun kecuali ia adalah orang yang bersalah."

9. Perjudian.

Yaitu setiap permainan antara dua kelompok yang akan munculkan kerugian di satu pihak dan keuntungan dipihak lain, baik berdasar kesepakatan atau kemujuran. Perbuatan ini digolongkan al Maisir seperti kesepakatan para ulama. Dalil AlQur'an yang menunjukkan keharaman judi adalah:

"Hai orang-orang yang beriman, Sesungguhnya (meminum) khamar, berjudi, (berkorban untuk) berhala, mengundi nasib dengan panah, adalah termasuk perbuatan syaitan. Maka jauhilah perbuatan-perbuatan itu agar kamu mendapat keberuntungan". (Al Maidah: 90)

Dalam perspektif ekonomi Islam, investasi bukanlah melulu bercerita tentang berapa keuntungan materi yang bisa didapatkan melalui aktivitas investasi, tapi ada beberapa faktor yang mendominasi motifasi investasi dalam Islam. Pertama, akibat implementasi mekanisme zakat maka asset produktif yang dimiliki seseorang pada jumlah tertentu (memenuhi batas nisab zakat) akan selalu dikenakan zakat, sehingga hal ini akan mendorong pemiliknya untuk mengelolanya melalui investasi. Dengan demikian melalui investasi tersebut pemilik asset memiliki potensi mempertahankan jumlah dan nilai assetnya. Berdasarkan argumentasi ini, aktifitas investasi pada dasarnya lebih dekat dengan prilaku individu (investor/muzakki) atas kekayaan atau 
asset mereka daripada prilaku individu atas simpanan mereka. Sejalan dengan kesimpulan bahwa sebenarnya ada perbedaan yang mendasar dalam perekonomian Islam dalam membahas perilaku simpanan dan investasi, dalam Islam investasi lebih bersumber dari harta kekayaan/asset daripada simpanan yang dalam investasi dibatasi oleh definisi bagian sisa dari pendapatan setelah dikurangi oleh konsumsi. Kedua, aktivitas investasi dilakukan lebih didasarkan pada motifasi social yaitu membantu sebagian masyarakat yang tidak memiliki modal namun memiliki kemampuan berupa keahlian (skill) dalam menjalankan usaha, baik dilakukan dengan bersyarikat (musyarakah) maupun dengan berbagi hasil (mudharabah). Jadi dapat dikatakan bahwa investasi dalam Islam bukan hanya dipengaruhi factor keuntungan materi, tapi juga sangat dipengaruhi oleh faktor syariah (kepatuhan pada ketentuan syariah) dan faktor sosial (kemashlahatan ummat).

Maka golongan masyarakat yang aktif melakukan aktifitas investasi adalah golongan masyarakat muzakki. Golongan masyarakat ini memiliki potensi melakukan investasi akibat sumber daya ekonominya berlebih setelah memenuhi kebutuhan dasar dan kebutuhan untuk berjaga-jaga. Investasi ini tentu akumulasi dan perannya dalam perekonomian secara makro sangat besar. Dengan berfungsinya sistem zakat dan dilarangnya riba serta spekulasi, maka akumulasi dana besar yang dimiliki oleh golongan muzakki akan ditransfer menjadi investasi, sebagai reaksi untuk menghindari risiko berkurangnya harta mereka akibat kewajiban zakat dan motif ingin menjaga atau bahkan menambah jumlah kekayaan (harta) para muzakki. Berarti akumulasi investasi tersebut akan terus berputar dan berputar. Dengan begitu tingkat velocity akan terjaga atau bahkan akan terus meningkat seiring dengan peningkatan jumlah akumulasi investasi. Jadi dapat disimpulkan investasi dalam Islam ditentukan oleh beberapa variabel yang diantaranya adalah ekspektasi keuntungan pada sebuah projek, pendapatan dan kondisi perekonomian (bukan oleh tingkat bunga yang selama ini dikenal dalam teori ekonomi konvensional) 


\section{DAFTAR PUSTAKA}

\section{Al-Qu'ran Al-Karim}

Antonio, Muhamad Syafi'i. 2001, Cet. ke-1. Bank Syariah dari Teori ke Praktek. Jakarta : Gema Insani

Bachtiar Surin. 2002. Az-zikra. Terjemahan dan Tafsir Al-Qur'an dalam huruf Arab dan Latin, Bandung: Angkasa

Hamka. 1999. Tafsir Al-Azhar Juzu' XI, Jakarta: Pustaka Panjimas

Halim, A. 2005. Analisis investasi. Jakarta: Salemba Empat

Jumingan. Cet. Pertama 2009. Studi Kelayakan Bisnis, Teori dan Pembuatan Proposal Kelayaka. Jakarta: Bumi Aksara

Metwally, 1995, Cet. Ke-1. Teori dan Praktek Ekonomi Islam, Jakarta: Bangkit Daya Insani,

Huda Nurul dan Mustafa Edwin Nasution. 2008. Investasi pada Pasar Modal Syariah, Cetakan kedua. Jakarta: Kencana Prenada Media Group.

Shihab, Quraish. 2002, Cet. ke-1, Volume 6. Tafsir Al-Misbah, Jakarta: Lentera Hati

Shihab, Quraish. 1996. Wawasan Al-Qur'an :Tafsir Maudhu'i Atas Pelbagai Persoalan Umat , Jakarta: Mizan

Tandelilin, Eduardus. 2001. Analisis Investasi \& Manajemen Portofolio. Yogyakarta: BPFE 